\title{
Host specificity and phylogenetic relationships among Atlantic Ovulidae (Mollusca: Gastropoda)
}

\author{
Bastian T. Reijnen ${ }^{1,2}$, Bert W. Hoeksema ${ }^{1}$, Edmund Gittenberger ${ }^{1}$ \\ ${ }^{1}$ Department of Marine Zoology, Netherlands Centre for Biodiversity Naturalis, PO Box 9517, NL 2300 RA Leiden, \\ The Netherlands \\ ${ }^{2}$ E-mail: reijnen@naturalis.nl
}

Key words: Anthozoa, Alcyonacea, Caribbean, Curaçao, molecular phylogeny, symbiosis

\begin{abstract}
Ovulid gastropods and their octocoral hosts were collected along the leeward coast of Curaçao, Netherlands Antilles. New molecular data of Caribbean and a single Atlantic species were combined with comparable data of Indo-Pacific Ovulidae and a single East-Pacific species from GenBank. Based on two DNA markers, viz. CO-I and $16 \mathrm{~S}$, the phylogenetic relationships among all ovulid species of which these data are available are reconstructed. The provisional results suggest a dichotomy between the Atlantic and the Indo-Pacific taxa. Fully grown Simnialena uniplicata closely resembles juvenile Cyphoma gibbosum conchologically. Cymbovula acicularis and C. bahamaensis might be synonyms. The assignments of Caribbean host species for Cyphoma gibbosum, C. signatum, Cymbovula acicularis and Simnialena uniplicata are revised.
\end{abstract}

\section{Contents}

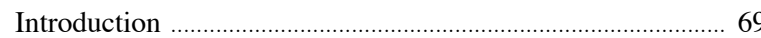

Material and methods ……………………………………..... 70

Molecular analyses ............................................................ 70

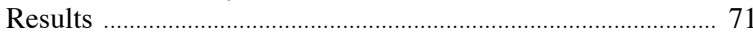

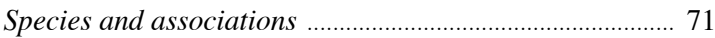

Phylogeny reconstruction .................................................... 72

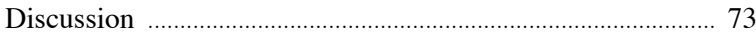

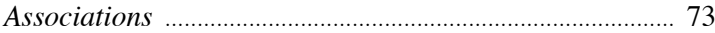

Paedomorphosis .................................................................... 75

Systematics, biogeography and nomenclature ................... 76

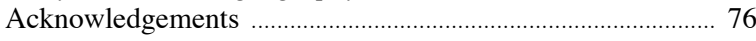

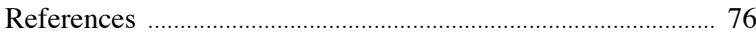

\section{Introduction}

Ovulid snails are obligate associates of Cnidaria. As far as known, most occur associated with octocorals (Anthozoa: Octocorallia: Alcyonacea), but in both the Caribbean and the Indo-Pacific some ovulid species feed on antipatharians (Anthozoa: Hexacorallia: Antipatharia) (Tazioli et al., 2007). The species of Pedicularia Swainson, 1840, that have been classified with the Ovulidae for a long time (Goud and Hoeksema, 2001), live on stylasterid corals (Hydrozoa: Athecatae: Filefera). Pedicularia differs from the undisputed ovulids in radula morphology (Simone, 2004); it is now classified in the separate family Pediculariidae (Fehse, 2007; Lorenz and Fehse, 2009).

Thirty-seven species of Ovulidae Fleming, 1822, are known from the Caribbean and Atlantic area (Lorenz and Fehse, 2009). The dominant genus in the Caribbean is Cyphoma Röding, 1798, with 14 species of which Cyphoma gibbosum (Linnaeus, 1758) is the most common. Due to the low number of ovulid species in the Caribbean and the well-known diversity of Octocorallia (Bayer, 1961) parasite/host relationships are most easily studied here.

It has been hypothesized that colour patterns and texture of ovulid mantles may either mislead potential predators by mimicking its host's branches and polyps, or that its colour acts as a warning of unpalatability (aposematic species) (Rosenberg, 1992; Schiaparelli et al., 2005). Snails closely resembling coral branches and polyps of their host may be camouflaged in such a way that they are almost undetectable for predators, such as shown by the Caribbean Cymbovula acicularis (Lamarck, 1810), which uses its mantle colour and protrusions to mimic the branches and polyps of its gorgonian host (Fig. 1d).

As a first step to a better understanding of the associations between alcyonaceans and ovulids, Yamamoto (1972) and Schiaparelli et al. (2005) studied the snails and their hosts in the Indo-Pacific. In the present paper we primarily deal with the Ovulidae and their octocoral hosts of the Caribbean island of Curaçao. Our new data on species associations are used to investigate whether the gastropod species should be considered generalists or specialists. Based on of the molecular data from this study and GenBank, a provisional molecular phylogeny reconstruction of Ovulidae is presented. 


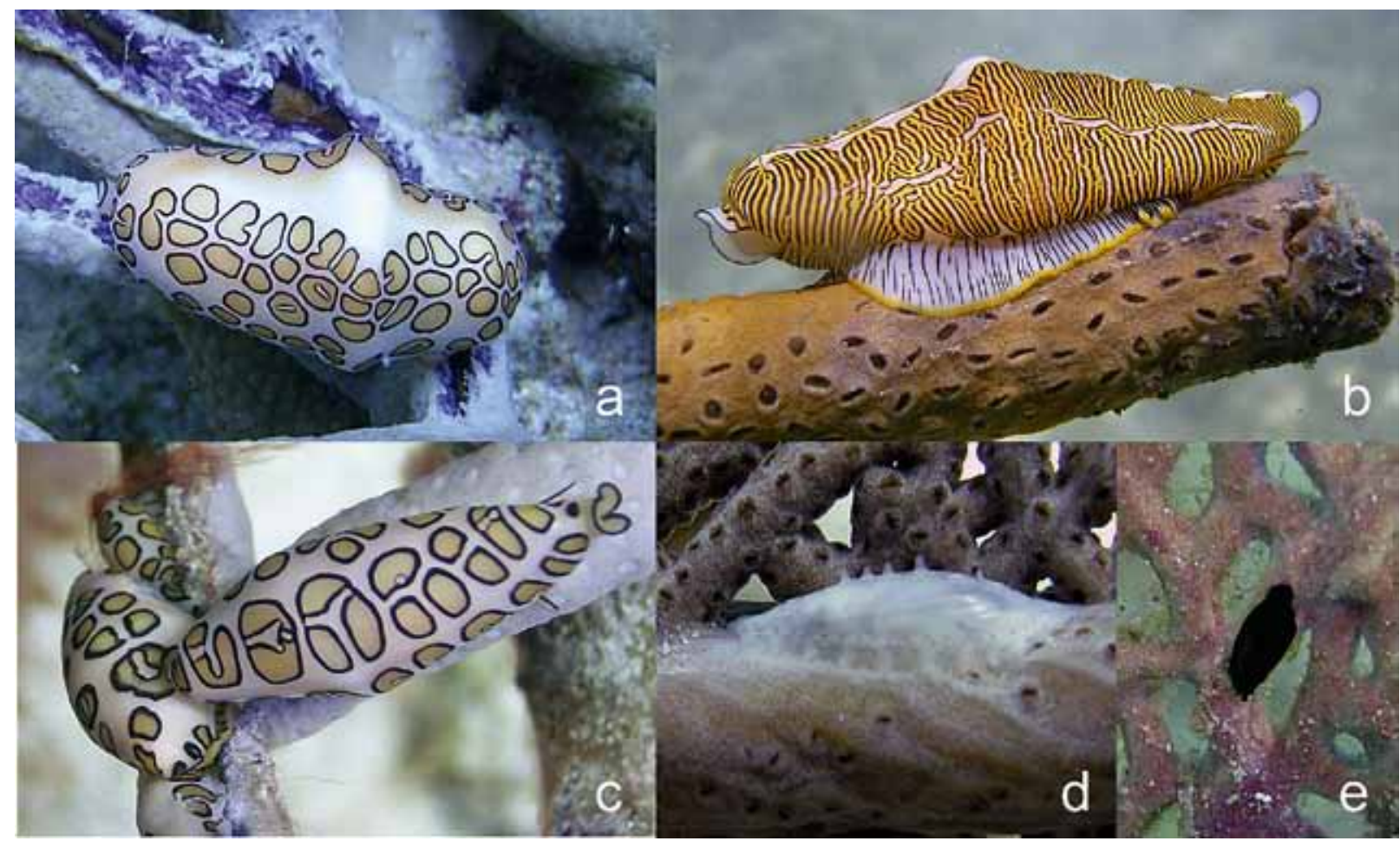

Fig. 1. Species in situ. a) Cyphoma gibbosum; b) C. signatum; c) C. gibbosum (juvenile); d) Cymbovula acicularis; e) Simnialena uniplicata (juvenile).

\section{Material and methods}

In April - June 2005, both ovulid snails and their octocoral hosts were sampled using SCUBA diving at 32 localities off the leeward western coast of Curaçao, Netherlands Antilles. Observations on the windward eastern shore were hampered by exposure to the open sea. All snails and hosts were photographed in situ and collected by hand, and subsequently stored as vouchers in the collection of NCB Naturalis. Three species of the Atlantic ovulid Simnia patula (Pennant, 1777), dredged from the Dutch North Sea bottom by fishermen, were added as additional samples for the phylogeny reconstruction.

For the Ovulidae the nomenclature accepted by the 'Checklist of European Marine Mollusca' (CLEMAM, 2008) and Cate (1973) was followed, except for Neosimnia aequalis sensu stricto (not Sowerby II, 1832), which is referred to as $N$. arcuata (Reeve, 1865), in accordance with Lorenz and Fehse (2009). The status of the former nominal taxon will remain uncertain as long as no valid lectotype selection has taken place, but this cannot affect the use of the latter name.

\section{Molecular analyses}

For molecular phylogeny reconstructions, tissue samples from the foot of the snails were used to extract DNA with the E.Z.N.A. Mollusc DNA Kit (Omega Biotek). The primer sets published by Meyer (2003) and Schiaparelli et al. (2005) were used to amplify the mtDNA markers CO-I and 16S marker, respectively. The PCR reaction mixtures were composed after Gittenberger et al. (2006). For 16S, 0,005 ml MilliQ was replaced by an equal volume of Qsolution (Qiagen). The annealing temperature used for $16 \mathrm{~S}$ was set at $52^{\circ}$, whereas for CO-I a ramp was used, starting at $40^{\circ}$ and ending at $44^{\circ}$, increasing with $0.1^{\circ} \mathrm{s}^{-1}$.

Sequencing was performed on a MegaBace 1000, 96 capillary sequencer at Leiden University, and on an Automatic Sequencer 3730xl by Macrogen, Korea. The raw sequence data were assembled and edited using Sequencher 4.2 (Gene Codes Corporation ${ }^{\circledast}$ ) and aligned with ClustalX. The sequences in the CO-I dataset were all checked for stop codons. All sequences were referenced against GenBank (National Center for Biotechnology Information, NCBI) to ensure that non-targeted DNA had not been sequenced. For the 
Table 1. Newly sequenced species with GenBank accession numbers and sequence data obtained from GenBank, referring to (S) Schiaparelli et al. (2005) and (M) Meyer (2003).

\begin{tabular}{|c|c|c|}
\hline species & $16 \mathrm{~S}$ accession number & CO-I accession number \\
\hline Adamantia florida (Kuroda, 1958) & AY 161396 (M) & AY 161629 (M) \\
\hline Calpurnus lacteus (Lamarck, 1810) & AY 161398 (M) & AY 161631 (M) \\
\hline Calpurnus verrucosus (Linnaeus, 1758) & AY 161397 (M) & AY $161630(\mathrm{M})$ \\
\hline Crenavolva cf. rosewateri Cate, 1973 & AY 161394 (M) & AY 161627 (M) \\
\hline Crenavolva tokuoi Azuma, 1989 & AY 161390 (M) & AY $161623(\mathrm{M})$ \\
\hline Cyphoma gibbosum Linnaeus, 1758 & AY $161400(\mathrm{M})$ & AY $161633(\mathrm{M})$ \\
\hline Cyphoma gibbosum Linnaeus, 1758 & GU 363427 & GU 363439 \\
\hline Cyphoma gibbosum Linnaeus, 1758 & GU 363428 & GU 363440 \\
\hline Cyphoma gibbosum Linnaeus, 1758 & GU 363429 & GU 363441 \\
\hline Cyphoma gibbosum Linnaeus, 1758 & GU 363430 & GU 363442 \\
\hline Cyphoma gibbosum Linnaeus, 1758 & GU 363431 & GU 363443 \\
\hline Cyphoma gibbosum Linnaeus, 1758 & GU 363432 & GU 363444 \\
\hline Cyphoma gibbosum Linnaeus, 1758 & GU 363433 & GU 363445 \\
\hline Cymbovula acicularis (Lamarck, 1810) & GU 363434 & GU 363446 \\
\hline Cymbovula acicularis (Lamarck, 1810) & GU 363436 & GU 363448 \\
\hline Cymbovula acicularis (Lamarck, 1810) & GU 363437 & GU 363449 \\
\hline Cypraea tigris (Linnaeus, 1758) & AY 161489 (M) & AY $161722(\mathrm{M})$ \\
\hline Dentiovula takeoi Cate \& Azuma, 1973 & AY 534354 (M) & AY $534431(\mathrm{M})$ \\
\hline Jenneria pustulata Lightfoot, 1786 & AY $161402(\mathrm{M})$ & AY $161635(\mathrm{M})$ \\
\hline Neosimnia arcuata (Reeve, 1865) & AY 161401 (M) & AY $161634(\mathrm{M})$ \\
\hline Ovula ovum (Linnaeus, 1758) & AY 161399 (M) & AY $161632(\mathrm{M})$ \\
\hline Phenacovolva tokioi (Cate, 1973) & AY 161393 (M) & AY $161626(\mathrm{M})$ \\
\hline Phenacovolva weaveri Cate, 1973 & AJ $868565(S)$ & AY 161628 (M) \\
\hline Primovula concinna Adams \& Reeve, 1848 & AY $534353(\mathrm{M})$ & AY $534430(\mathrm{M})$ \\
\hline Prionovolva brevis Sowerby I, 1828 & AY $161391(\mathrm{M})$ & AY $161624(\mathrm{M})$ \\
\hline Prosimmia semperi (Weinkauff, 1881) & AJ $868548(S)$ & AY $534432(\mathrm{M})$ \\
\hline Simnia patula (Pennant, 1777) & GU 363438 & GU 363450 \\
\hline Simnialena uniplicata (Sowerby II, 1848) & GU 363435 & GU 363447 \\
\hline Volva volva (Linnaeus, 1758) & AY $534352(\mathrm{M})$ & AY 534429 (M) \\
\hline
\end{tabular}

phylogeny reconstruction, 17 GenBank sequences for both $16 \mathrm{~S}$ and CO-I (Table 1), representing the same species, were combined with sequences of the Atlantic species. For the single individual of Cyphoma signatum, CO-I could not be amplified. Therefore, this species was excluded from the dataset. The final alignment consisted of 28 sequences containing 961 base pairs. Newly sequenced species are deposited in GenBank under accession numbers GU363427 - GU363450.

Within $16 \mathrm{~S}$ highly variable regions exist, formed by either insertions or deletions. Aligning this region proved to be very difficult and the unalignable region, consisting of 75 base pairs in length (position 166 till 241), was deleted. To check whether both datasets could be combined, an incongruence length difference test (ILD-test) was performed. This test resulted in a $\mathrm{P}$-value $(\mathrm{P}=1.00)$ allowing the data combination. To determine the optimal evolutionary models the combined molecular dataset was subjected to Modeltest (Posada and Crandall, 1998). This resulted in the Generalised Time Reversible evolutionary model + invari- able sites + gamma (GTR I+G). The obtained parameters were used to run a maximum likelihood search in PAUP* 4.0b (Swofford, 2003). No fewer than a 100 bootstrap replicates were used to evaluate the robustness of the nodes. The search was carried out with tree bisection-reconnection (TBR). Gaps were in all cases treated as missing character and not as a fifth character state. The selected outgroup sequence was that of the cypraeid Cypraea tigris (Linnaeus, 1758).

\section{Results}

\section{Species and associations}

A total of 104 samples of ovulids was collected, representing viz. Cyphoma gibbosum (Linnaeus, 1758), Cyphoma signatum Pilsbry and McGinty, 1939, Simnialena uniplicata (Sowerby II, 1848) and Cymbovula acicularis (Lamarck, 1810) (Fig. 2, including specimen resembling the so-called C. bahamaensis). The 72 
Table 2. Host-species associations between Ovulidae and Octocorallia.

\begin{tabular}{|c|c|c|c|c|}
\hline Octocoral taxa & $\begin{array}{l}\text { Cyphoma } \\
\text { gibbosum }\end{array}$ & $\begin{array}{l}\text { Cyphoma } \\
\text { signatum }\end{array}$ & $\begin{array}{l}\text { Cymbovula } \\
\text { acicularis }\end{array}$ & $\begin{array}{r}\text { Simnialena } \\
\text { uniplicata }\end{array}$ \\
\hline \multicolumn{5}{|l|}{ Briareidae } \\
\hline Briareum asbestinum (Pallas, 1766) & 3 & - & - & - \\
\hline \multicolumn{5}{|l|}{ Gorgoniidae } \\
\hline Gorgonia flabellum Linnaeus, 1758 & 3 & - & 2 & 2 \\
\hline G. mariae Bayer, 1961 & - & - & 1 & - \\
\hline G. ventalina Linnaeus, 1758 & 5 & - & 12 & 2 \\
\hline Pseudopterogorgia acerosa (Pallas, 1766) & 4 & - & 5 & - \\
\hline P. americana (Gmelin, 1791) & 11 & - & - & - \\
\hline P. bipinnata (Verrill, 1864) & 2 & - & 7 & - \\
\hline P. rigida (Bielschowsky, 1929) & 2 & - & - & - \\
\hline Pterogorgia citrina (Esper, 1792) & 1 & - & - & - \\
\hline \multicolumn{5}{|l|}{ Plexauridae } \\
\hline Eunicea calyculata (Ellis \& Sollander, 1786) & 3 & - & - & - \\
\hline E. clavigera Bayer, 1961 & 4 & - & - & - \\
\hline E. knightyi Bayer, 1961 & 2 & - & - & - \\
\hline E. succinea (Pallas, 1766) & 1 & & - & - \\
\hline E. tourneforti Milne Edwards \& Haime, 1857 & 6 & - & - & - \\
\hline Muricia muricata (Pallas, 1766) & 2 & - & - & - \\
\hline Plexaura flexuosa Lamouroux, 1821 & 7 & & - & - \\
\hline P. homomalla (Esper, 1792) & 1 & - & - & - \\
\hline Plexaurella dichotoma (Esper, 1791) & 3 & 1 & - & - \\
\hline P. grisea Kunze, 1916 & 2 & - & - & - \\
\hline P. nutans (Duchassaing \& Michelotti, 1860) & 1 & - & - & - \\
\hline Pseudoplexaura porosa (Houttuyn, 1772) & 6 & - & - & - \\
\hline Unidentified & 3 & - & - & - \\
\hline
\end{tabular}

snails of Cyphoma gibbosum that could be studied were found with 21 alcyonacean species, representing nine genera. The 27 individuals of Cymbovula acicularis were found in association with five gorgoniid species, belonging to two genera. Simnialena uniplicata occurred with two congeneric host species, but since only four individual snails were found, it would be premature to derive any conclusions about host specificity. Unfortunately, only a single specimen of $\mathrm{Cy}$ phoma signatum could be studied, which was associated with Plexaurella dichotoma (Esper, 1791). This gorgonian species was also mentioned by Botero (1990), who additionally reported the congeneric $P$. nutans as a host for $C$. signatum. Due to the poverty of its records, the host preferences of this ovulid remain largely unknown.

From a total of 46 octocoral species recorded at Curaçao, 26 (57\%) were found to be occasionally parasitized by one or more ovulid species (Table 2). Not all encountered Octocorallia species were found associated with ovulids. Additionally, a list was composed (Table 3) of encountered Octocorallia without associated ovulids.

\section{Phylogeny reconstruction}

Cyphoma gibbosum is a common Caribbean species that is easily recognized by its colour pattern and morphology. To exclude possible sibling species occurring on, for example, different hosts or at other localities at Curaçao, several individuals from different Octocorallia species and from different localities along the coast were sequenced. Based on the molecular data no sibling species occurrence was detected. In Fig. 3 the results of the combined dataset subjected to a maximum likelihood analysis (ML) with bootstrap values is presented.

The phylogeny reconstruction indicates that there is a separation between the Atlantic and the Indo-Pacific clade (moderately supported, bootstrap value 70), although the East-Pacific species Neosimnia arcuata clusters with the Atlantic clade (poorly supported, bootstrap value 51). Simnialena uniplicata (Fig. 2f-g), Neosimnia arcuata and Cymbovula acicularis (Fig. 2a-d) are characterized conchologically by long and slender shells, but in the cladogram $S$. uniplicata does not appear as sister species to either $N$. arcuata 
Table 3. Overview of collected Octocorallia that were not found to be parasitized by Ovulidae.

\section{Anthothelidae}

Erythropodium caribaeorum (Duchassaing \& Michelotti, 1860)

Ellisellidae

Ellisella barbadensis (Duchassaing \& Michelotti, 1864)

E. elongate (Pallas, 1766)

Plexauridae

Eunicea calyculata coronata Bayer, 1961

E. fusca (Duchassaing \& Michelotti, 1860)

E. laciniata Duchassaing \& Michelotti, 1860

E. mammosa Lamouroux, 1816

E. succinea plantaginea (Lamarck, 1815)

E. sp. A

Muricea atlantica (Kükenthal, 1919)

M. laxa Verrill, 1864

Plexaura nina Bayer \& Deichman, 1958

P. sp. A

Pseudoplexaura flagellosa (Houttuyn, 1772)

P. sp. A

$P$. sp. B

P. sp. C

Gorgoniidae

Pseudopterogorgia sp. A

P. sp. B

Pterogorgia guadelupensis Duchassaing \& Michelin, 1846 or C. acicularis. Instead, it forms a highly supported (bootstrap value 100) clade with the Cyphoma group. The individual sequence of the ovulid specimen resembling Cymbovula bahamaensis (Fig. 2c) forms a highly supported clade (bootstrap value 100) with the included C.acicularis species.

\section{Discussion}

\section{Associations}

Reported host preferences of Cyphoma gibbosum (Bertsch, 1984; Lasker et al., 1988; Botero, 1990; Nowlis, 1993; Chiaponne et al., 2003) are partly confirmed and supplemented with new observations of associations of this species, showing once more that $C$. gibbosum is a generalist parasite (Table 2). Cymbovula acicularis turned out to be another generalist.

It remains unclear why $43 \%$ of the encountered alcyonacean species did not appear as hosts for ovulids at the time of our fieldwork (Table 3). It is known that Octocorallia may produce secondary metabolites as

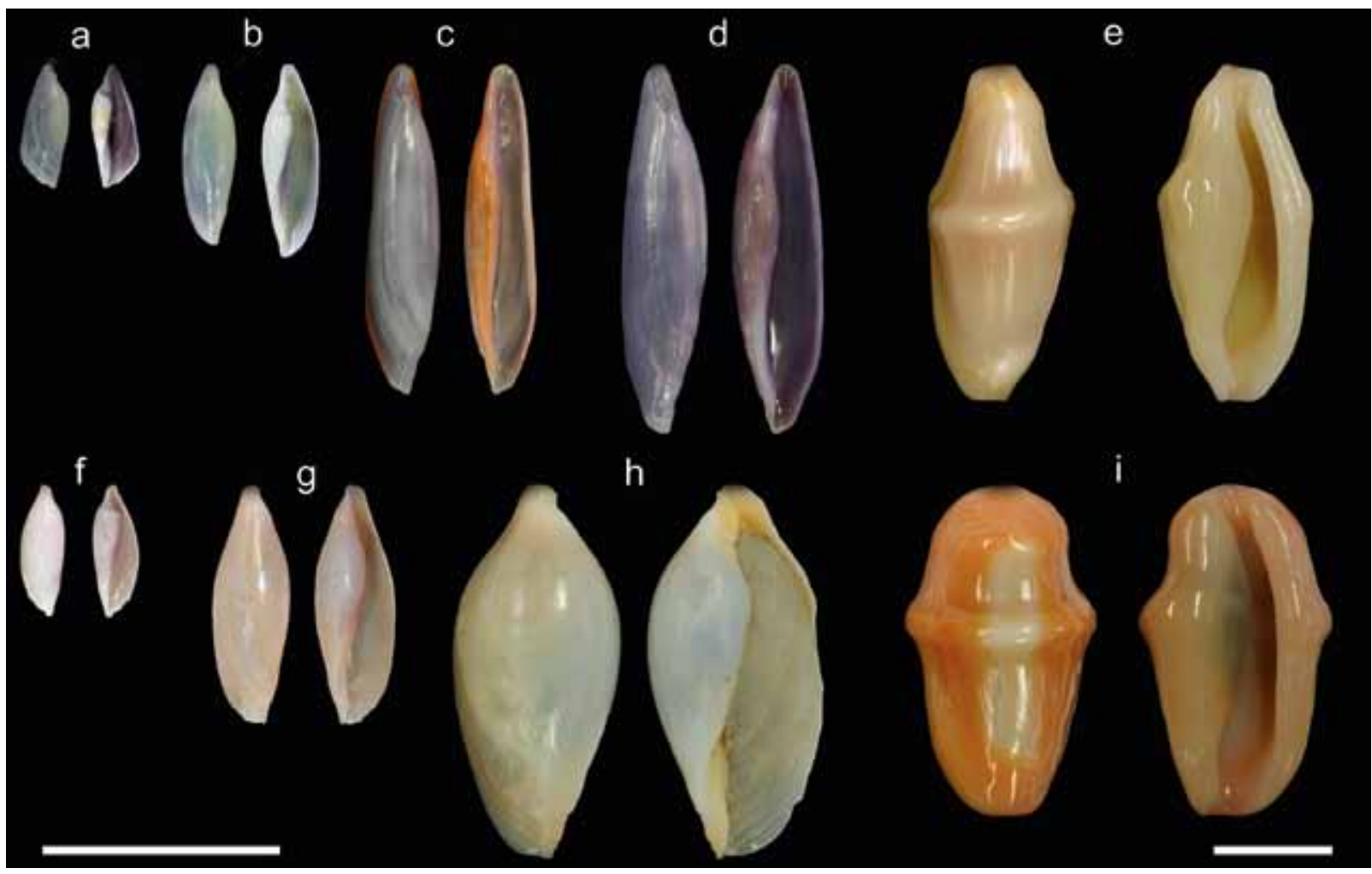

Fig. 2. Shells in dorsal and ventral view. a-d) Cymbovula acicularis (juvenile and adult); e) Cyphoma signatum; f-g) Simnialena uniplicata (juvenile); h) Simnia patula; i) Cyphoma gibbosum. Scale bars $1 \mathrm{~cm}$ (left, for a-d and f-h; right, for e and i). 


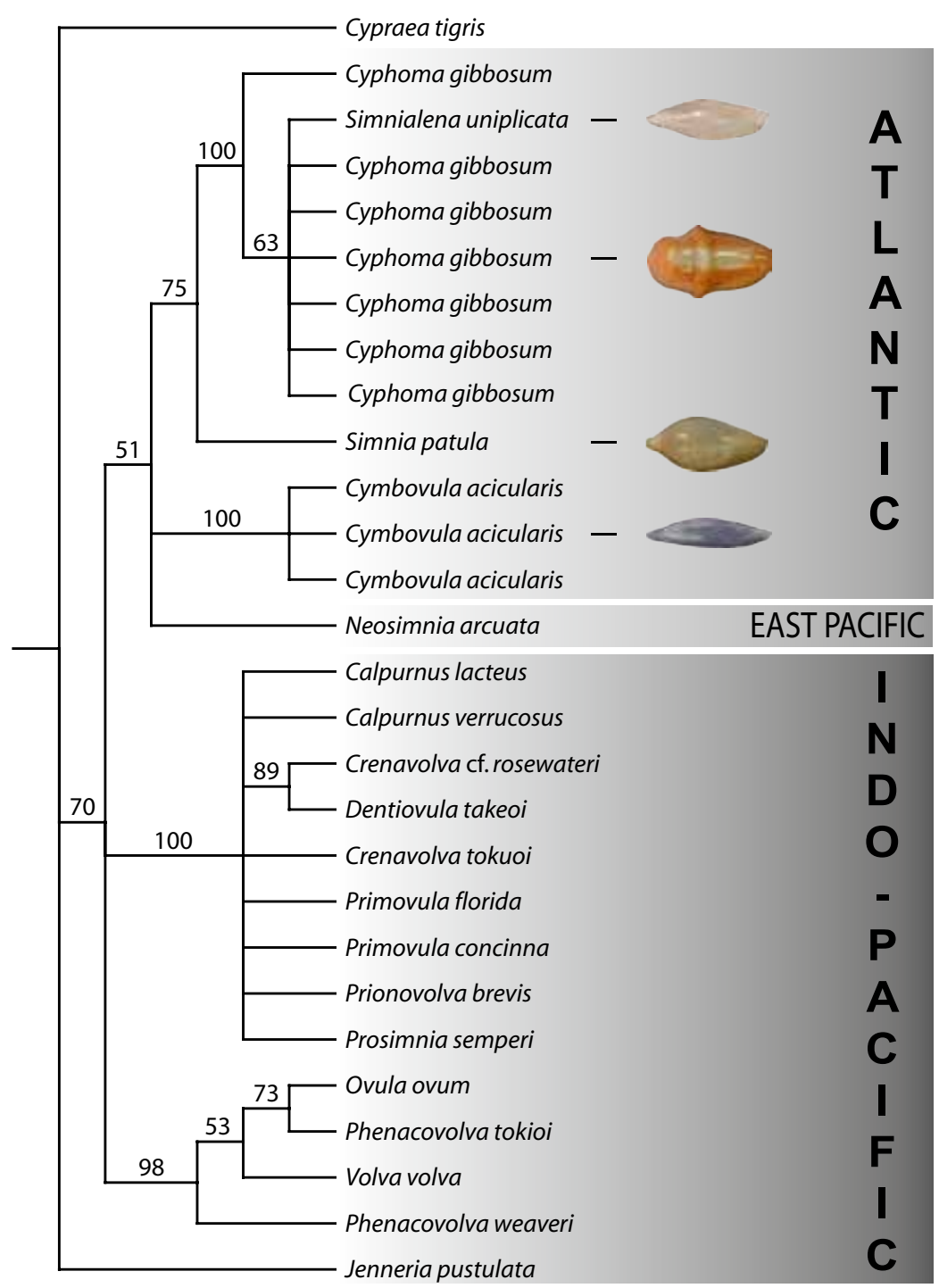

Fig. 3. Maximum likelihood analysis for combined Atlantic and Indo-Pacific Ovulidae based on $16 \mathrm{~s}$ and CO-I data. The values above the branches represent bootstrap values (100 replicates). protection against predation (Ciereszko and Schneider, 1987; Chiaponne et al., 2003), but the effect of this defence strategy on ovulids is still largely unexplored. Other factors, such as the nutritional value of the corals (O'Neal and Pawlik, 2002) and the unpalatability of sclerites (Alstyne and Paul, 1992), may also influence host choices.

An overview of natural products produced by West Indian gorgonian octocorals reveals that many types of secondary metabolites are found. The largest class of metabolites encountered in Caribbean alcyonaceans are diterpenoids, followed by the sesquiterpenes (Rodriguez, 1995). For some of these compounds that are obtained from alcyonaceans, such as Erythropodium caribeorum, feeding experiments were performed, resulting in the observation that coral extracts are deterrent to fish. Also, crude extracts from the gorgonian Gorgonia ventalina, containing terpenoids, were used in feeding experiments with C. gibbosum. As a result, C. gibbosum consumed only $49 \%$ of an artificial diet containing terpenoids (Alstyne and Paul, 1992).

The sclerites of the gorgonian species that we found as hosts for Simnialena uniplicata and Cymbovula acicularis turned out to be relatively small. The sclerites of Gorgonia spp. and Pseudopterogorgia spp. have average sizes of $0.10 \mathrm{~mm}$ and $0.10-0.15 \mathrm{~mm}$, respectively, whereas $0.30-1.00 \mathrm{~mm}$ is common for other Octocorallia species, like Eunicea and Pseudo- 


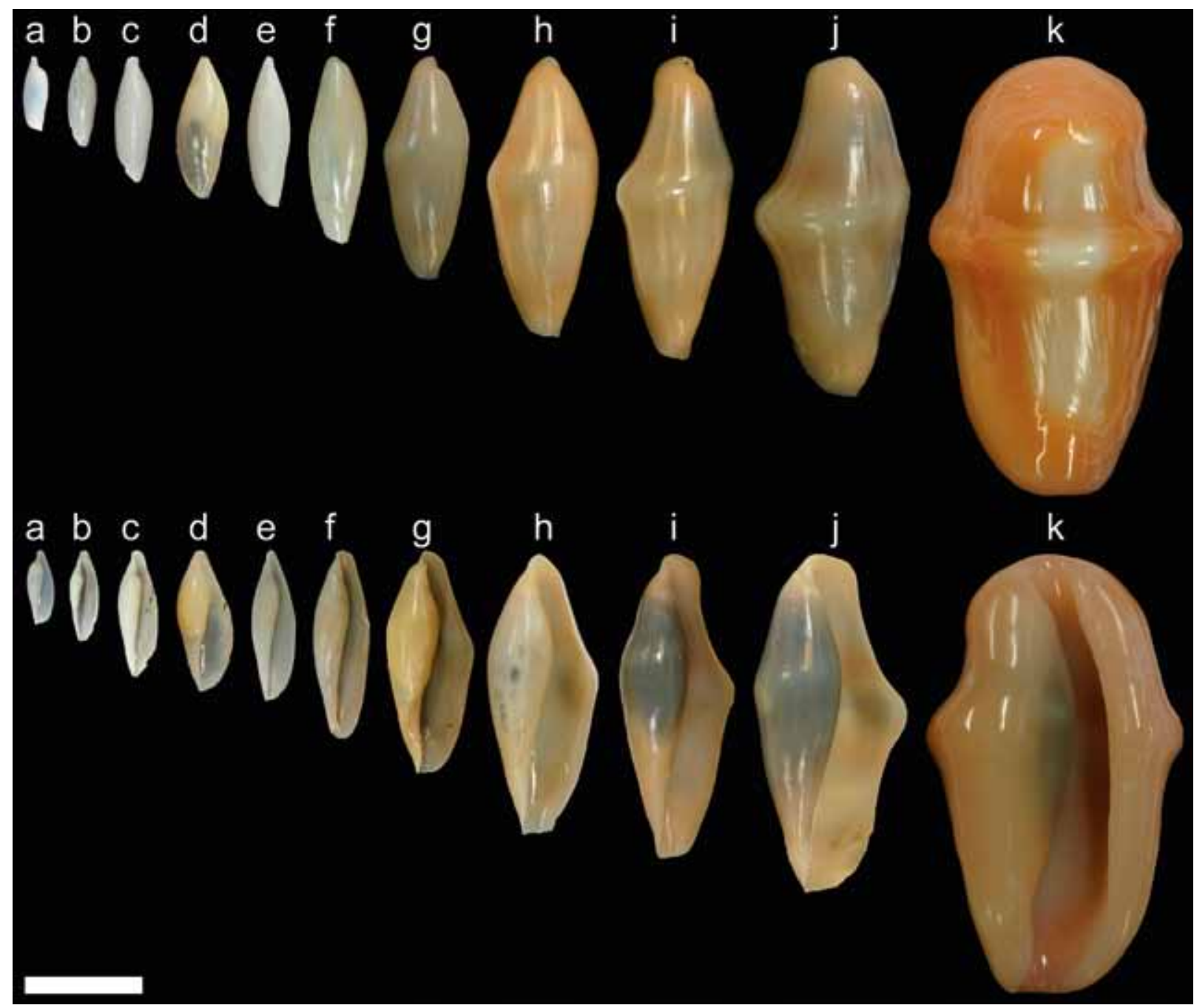

Fig. 4. Shells in dorsal and ventral view. Simnialena uniplicata (d) compared to a series of shells of Cyphoma gibbosum (a-c, e-k) in different developmental stages. Scale bar $1 \mathrm{~cm}$.

plexaura species (Bayer, 1961). For Cyphoma gibbosum, however, the sclerites' size seems to be irrelevant for host selection, since this species is found on corals containing either small or large sclerites. By analysing faecal pellets which all contained sclerites, we conclude that $C$. gibbosum at least ingests sclerites instead of eating around them.

\section{Paedomorphosis}

In the phylogeny reconstruction, Simnia patula is the sister group of the combined Simnialena uniplicata and Cyphoma species group. This is surprising because, at first sight, fully grown individuals of Cypho- $m a$ species clearly differ from $S$. uniplicata in shell morphology. However, when shells of S. uniplicata are compared to a series of shells of $C$. gibbosum in various growth-stages (Fig. 4), it turns out that $S$. uniplicata closely resembles juvenile $C$. gibbosum (as well as juvenile ovulids in general). Both species lack a clear funiculum (narrow ridge of callus at the ventral side of the shell close to the aperture) and have rounded, tapering ends, character states that are absent in fully grown $C$. gibbosum. Identification of juvenile ovulid shells is difficult, if not impossible, due to a lack of diagnostic shell characters. However, some specimens that were collected alive showed a mantle colour pattern diagnostic for $C$. gibbosum, viz. bright 
orange spots, encircled with a black line at a whitish background (Fig. 1). Cymbovula acicularis had a nearly transparent mantle, sometimes with white protuberances. In Simnialena uniplicata the mantle is entirely black, whereas in Cyphoma signatum it had a distinct yellow/ black fingerprint pattern. This leads to the conclusion that the mantle colour and pattern may be diagnostic in Ovulidae (Mase, 1989) and that this character can be used to distinguish fully grown Simnialena uniplicata from juvenile $C$. gibbosum. Therefore, we hypothesize that $S$. uniplicata exemplifies paedomorphosis.

\section{Systematics, biogeography and nomenclature}

According to the principles of phylogenetic systematics, the species referred to as Simnialena uniplicata should be called Cyphoma uniplicata (Fig. 3). Meanwhile, the status of the nominal genus Simnialena Cate, 1973, with its insufficiently known type species Simnialena marferula Cate, 1973, remains unclear. According to Lorenz and Fehse (2009: 105), 'S. marferula is a close relative of $S$. uniplicata'. This conclusion, on which we cannot elaborate here, is based on similarities in shell morphology.

The DNA sequences of specimens belonging to Cymbovula acicularis and specimens that agree with the description of C. bahamaensis (Figs 2c-d) are almost identical. As a consequence, these nominal taxa should most probably be considered synonyms, as has also been suggested by Lorenz and Fehse (2009) based on morphological data.

There is a moderately strong supported dichotomy between the Atlantic and the Indo-Pacific taxa, with Neosimnia arcuata from the East-Pacific having an aberrant, but poorly supported, position in the cladogram, where it clusters with the Atlantic taxa. Together, these species represent the Simniinae Schilder, 1927. Furthermore, two undisputed clades were found among the Indo-Pacific taxa, supporting the occurrence of the subfamilies Prionovolvinae Fehse, 2007, and Ovulinae Fleming, 1822, respectively.

In order to get a better understanding of the phylogeny and parasite/host associations of the Atlantic Ovulidae, additional shells and DNA material are needed. DNA obtained from other ovulids occurring in the Atlantic area (e.g. Cyphoma macumba Petuch, 1979; C. versicolor Fehse, 2003; C. mcgintyi Pilsbry, 1939) may elucidate the taxonomical position of the genus Cypho$m a$ as a monophyletic group. However, several ovulid species are rare and generally only their shells are found, which hampers further investigations.

\section{Acknowledgements}

We cordially thank the staff of CARMABI (Caribbean Research and Management of Biodiversity) foundation at Curaçao, The Netherlands Antilles, who provided us with accommodation, logistics, permits and laboratory space. We also like to thank Dr LP van Ofwegen and Mr FR Stokvis, who kindly identified the Octocorallia. Thanks are also due to Dr S Schiaparelli, who provided us with the primer sequences of the $16 \mathrm{~S}$ marker and Japanese ovulid literature, Ms K Way and Dr G Rosenberg, who assisted in solving a nomenclatorial puzzle, and Ms N Snijders, who collected the Cyphoma signatum specimen. Moreover, we would like to thank Prof. Dr SK Donovan, Ms SET van der Meij and anonymous reviewers for critically reviewing the manuscript.

We are grateful for financial support from: the Schure-Bijerinck-Popping Fonds (Royal Netherlands Academy of Arts and Sciences); the Jan Joost ter Pelkwijk Fonds, the Alida M Buitendijk Fonds and the Martin Stichting (NCB Naturalis); the LUF Internationaal Studie Fonds and the Lustra Fonds (Leiden University).

\section{References}

Adams A, Reeve LA. 1848-1850. Mollusca. Pp. i-x, 1-87 in: Adams A, ed., The zoology of the voyage of H.M.S. Samarang under the command of Sir Edward Belcher, during the years 1843-1846. London: Reeve, Benham and Reeve.

Alstyne KL van, Paul VJ. 1992. Chemical and structural defenses in the sea fan Gorgonia ventalina: effects against generalist and specialist predators. Coral Reefs 11: 155-159.

Azuma M. 1989. Systematic studies on the recent Japanese family Ovulidae (Gastropoda). XIV. Description of a new species of the genus Crenavolva Cate, 1973. Venus 48, Suppl. 3: 161-166.

Bayer FM. 1961. The shallow-water Octocorallia of the West Indian region. A manual for marine biologists. The Hague: Martinus Nijhoff.

Bayer FM, Deichmann E. 1958. Two new plexaurid gorgonians from the Bahama Islands. Bulletin of Marine Science of the Gulf and Caribbean 8: 224-235.

Bielschowsky E. 1929. Die Gorgonarien Westindiens. Kap. 6. Die Familie Gorgoniidae, zugleich eine Revision. Zoologische Jahrbuecher Suppl. 16: 63-234.

Bertsch H. 1984. The feeding, anatomy and reproductive biology of Cyphoma gibbosum. Shells and Sea Life 16: 100-101.

Botero L. 1990. Observations on the size, predators and tumorlike outgrowths of gorgonian Octocoral colonies in the area of Santa Marta, Caribbean coast of Colombia. Northeast Gulf Science 11: 1-10.

Cate CN. 1973. A systematic revision of the recent cypraeid family Ovulidae (Mollusca: Gastropoda). The Veliger 15 Suppl.: 1-116.

Cate CN, Azuma M. 1973. Dentiovula takeoi sp. nov. Pp. 15 in: Cate $\mathrm{CN}$, A systematic revision of the recent cypraeid family Ovulidae (Mollusca: Gastropoda). The Veliger 15 Suppl.: 1-116.

Chiaponne M, Dienes H, Swanson DW, Miller SL. 2003. Density and gorgonian host-occupation patterns by flamingo 
tongue snails (Cyphoma gibbosum) in the Florida Keys. Caribbean Journal of Science 39: 116-127.

Ciereszko LS, Schneider WP. 1987. Conversion of the prostaglandin (15S)- $\mathrm{PGA}_{2}$ to (15S)- $\mathrm{PGB}_{2}$ in the flamingo tongue snail Cyphoma gibbosum (L.) feeding on the gorgonian Plexaura homomalla. Bulletin of Marine Science 41: 634.

CLEMAM, 2008. Checklist of European Marine Mollusca. Public scientific database, Muséum national d'Histoire naturelle (MNHN), Paris. Available at: http://www.mnhn.fr/biotaxis/ clemam.

Duchassaing P, Michelin H. 1846. Note sur deux polypiers de la famille des couraux appartenant aux genres Solanderia et Pterogorgia. Revue Zoologique par la Société Cuvierienne 9: 218-220.

Duchassaing P, Michelotti J. 1860. Mémoire sur les coralliaires des Antilles. Memorie della Reale Accademia delle Scienze di Torino 19: 279-365.

Duchassaing P, Michelotti J. 1864. Supplément au mémoire sur les coralliaires des Antilles. Memorie della Reale Accademia delle Scienze di Torino 23: 97-206.

Ellis J, Solander D. 1786. The natural history of many curious and uncommon zoophytes, collected from various parts of the globe by the late John Ellis. Systematically arranged and described by the late Daniel Solander. London: Benjamin White and Son.

Esper EJC. 1791. Die Pflanzenthiere in Abbildungen nach der Natur mit Farben erleuchtet nebst Beschreibungen. Theil 2. Nürnberg: Raspischen Buchhandlung.

Esper EJC. 1792. Die Pflanzenthiere in Abbildungen nach der Natur mit Farben erleuchtet nebst Beschreibungen. Theil 2. Nürnberg: Raspischen Buchhandlung.

Fehse D. 2003. Contributions to the knowledge of the Ovulidae (Gastropoda: Cypraeoidea). XII. The Cyphoma-Pseudocyphoma complex II part. La Conchiglia 308: 11-38.

Fehse D. 2007. Contributions to the knowledge of the Ovulidae. XVI. The higher systematics (Mollusca: Gastropoda). Spixiana 30: 121-125.

Fleming J. 1822. The Philosophy of Zoology, or a general view of the structure, functions, and classification of animals. Edinburgh: Constable.

Gittenberger A, Reijnen BT, Hoeksema BW. 2006. A molecular analysis of the evolutionary history of mushroom corals (Scleractinia: Fungiidae) and its consequences for taxonomic classification. Pp. 35-56 in: Gittenberger A, The evolutionary history of parasitic gastropods and their coral hosts in the Indo-Pacific. PhD-thesis, Leiden University.

Gmelin JF. 1791. Caroli a Linne Systema Naturae per regna tria naturae, secundum classes, ordines, genera, species, cum characteribus, dif ferentiis, synonymis, locis. Editio decima tertia, aucta, reformata. Lipsiae: Georg Emanuel Beer.

Goud J, Hoeksema BW. 2001. Pedicularia vanderlandi spec. nov. (Gastropoda: Ovulidae), a symbiotic snail on the hydrocoral Distichopora vervoorti Cairns and Hoeksema, 1998 (Hydrozoa: Stylasteridae) from Bali, Indonesia. Zoologische Verhandelingen, Leiden 334: 77-97.

Houttuyn M. 1772. De Zee-Gewassen. Pp. 126-138 in: Natuurlyke Historie of uitvoerige Beschrijving der Dieren, Planten en Mineraalen, volgens het Samenstel van den Heer Linnaeus. Amsterdam: Houttuyn.
Kükenthal W. 1919. Gorgonaria. Wissenschaftliche Ergebnisse der Deutschen Tiefsee-Expedition auf dem Dampfer 'Valdivia' 1898-1899. Jena.

Kunze G. 1916. Die Gorgonarien Westindiens. Kap. 4, Die Gattung Eunicea Lamouroux; Kap. 5, Die Gattung Plexaurella. Zoologische Jahrbuecher Suppl. 11: 505-586.

Kuroda T. 1958. The Japanese species of Primovula series of the Amphiperatidae (Gastropoda). Venus 20: 167-173.

Lamarck JBPA de Monet de 1810. Sur la détermination des espèces parmi les animaux sans vertèbres, et particulièrement parmi les mollusques testacés. Annales du Muséum d'Histoire Naturelle Paris 15.

Lamarck, JBPA de Monet de 1815. Suite des polypiers empâtés. Mémoires du Muséum d'Histoire Naturelle Paris 1.

Lamouroux JVF. 1816. Histoire des polypiers coralligenes flexibles, vulgairement nommés Zoophytes. Caen: Poisson.

Lasker HR, Coffroth MA, Fitzgerald LM. 1988. Foraging patterns of Cyphoma gibbosum on Octocorals: the roles of host choice and feeding preference. Biological Bulletin 174: 254266 .

Lightfoot J. 1786. A catalogue of the Portland Museum, lately the property of the Duchess Dowager of Portland, deceased: which will be sold by auction etc. London.

Linnaeus C. 1758. Systema naturae. Editio decima, reformata. Holmiae: Impensis Direct. Laurentii Salvii.

Lorenz F, Fehse D. 2009. The living Ovulidae. A manual of the families of allied cowries: Ovulidae, Pediculariidae and Eocypraeidae. Hackenheim: ConchBooks.

Mase K. 1989. Taxonomic significance of color patterning of the soft body in the family Ovulidae, description of soft body of 26 species. Venus 1: 75-120.

Meyer CP. 2003. Molecular systematics of cowries (Gastropoda: Cypraeidae) and diversification patterns in the tropics. Biological Journal of the Linnean Society 79: 401-459.

Milne Edwards H, Haime J. 1857. Histoire naturelle des coralliaires ou polypes proprement dits. Vol. 1. Paris: Librairie Encyclopedique de Roret.

Nowlis JP. 1993. Mate- and oviposition-influenced host preferences in the coral-feeding snail Cyphoma gibbosum. Ecology 74: 1959-1969.

O’Neal W, Pawlik R. 2002. A reappraisal of the chemical and physical defences of Caribbean gorgonian corals against predatory fishes. Marine Ecology Progress Series 240: 117126.

Pallas PS. 1766. Elenchus zoophytorum sistens generum adumbrationes generaliores et specierum cognitarum succinctas descriptiones cum selectis auctorum synonymis. Hagae Comitum.

Pennant T. 1777. British zoology vol. 4 Crustacea, Mollusca, Testacea. London: White.

Petuch EJ. 1979. New gastropods from the Abrolhos Archipelago and reef complex, Brazil. Proceedings of the Biological Society of Washington 92: 510-526.

Pilsbry HA. 1938. Cyphoma Mcgintyi, new species. The Nautilus 50: 108.

Pilsbry HA, McGinty TL. 1939. The genus Cyphoma in Florida. The Nautilus 53: 1-4.

Posada D, Crandall KA. 1998. Modeltest: testing the model of DNA substitution. Bioinformatics 14: 817-818.

Reeve LA. 1865. Conchologia Iconica; monograph of the genus Ovulum. London: Reeve and Co. 
Röding PF. 1798. Museum Boltenianum, sive, Catalogus Cimeliorum e Tribus Regnis Naturae quae olim Collegerat Joa. Fried Bolten. Pars Secunda continens Conchylia sive Testacea Univalvia, Bivalvia and Multivalvia. Hamburg.

Rodriguez AD. 1995. The natural products chemistry of West Indian gorgonian Octocorals. Tetrahedron 51: 4571-4618.

Rosenberg G. 1992. An introduction to the Ovulidae (Gastropoda: Cypraeacea). American Conchologist 20: 4-7.

Schiaparelli S, Barucca M, Olmo E, Boyer M, Canapa A. 2005. Phylogenetic relationships within Ovulidae (Gastropoda: Cypraeoidea) based on molecular data from the 16S rRNA gene. Marine Biology 147: 411-420.

Schilder FA. 1925. Revision der Cypraeacea (Mollusca: Gastropoda). Archiv für Naturgeschichte, abteilung A 4: 179-214.

Simone LRL. 2004. Morphology and phylogeny of the Cypraeoidea (Mollusca, Caenogastropoda). Rio de Janeiro: Papel Virtual.

Sowerby GB. 1832. A catalogue of the recent species of Cypraeidae. The conchological illustrations. London.

Sowerby GB. 1848. Description of some new species of Ovulum in the collection of Mr. Cumming. Proceedings of the Zoological Society of London 16: 135-138.

Swainson W. 1840. A treatise on malacology or shells and shellfish. London: Longman, Orme, Brown, Green and Longmans.
Swofford DL. 2003. PAUP*. Phylogenetic Analysis Using Parsimony (*and other methods). Version 4.0b. Sunderland (MA): Sinauer Associates.

Tazioli S, Bo M, Boyer M, Rotinsulu H, Bavastrello G. 2007. Ecological observations of some common antipatharian corals from the marine park of Bunaken (North Sulawesi, Indonesia). Zoological Studies 46: 227-241.

Verrill AE. 1864. Revision of the polypi of the eastern coast of the United States. Memorial meeting of the Boston Society of Natural History 1: 1-45.

Weinkauff HC. 1881. Die Gattungen Cypraea und Ovula. Pp. 167-215 in: Martini and Chemnitz' Systematisches Conchylien Cabinet. Nurnberg: Bauer and Raspe.

Yamamoto T. 1972. Molluscs symbiotic with coelenterates in Japan, with special reference to Ovulidae and allied forms. Publications of the Seto Marine Biological Laboratory 20: 567-581.

Received: 14 October 2009

Accepted: 10 March 2010

Published online: 16 April 2010

Editor: J.W. Arntzen 